\title{
Strategic Management Tools and Techniques and Organizational Performance: Findings from the Czech Republic
}

- Afonina Anna

\begin{abstract}
The purpose of this study is to investigate the current level of strategic management tools and techniques utilization as well as to explore and identify the impact of management tools on organizational performance in the Czech Republic. The research paper is based on a questionnaire survey obtained from the 91 companies. This paper is one of the few studies which investigate the relationship between management tools and techniques and organizational performance. The findings show the level of management tools utilization and possibilities influencing performance. The study indicates that there is a positive significant relationship between management tools and techniques utilization and organizational performance.
\end{abstract}

Keywords: management tools and techniques, organizational performance, relationship, Czech Republic JEL Classification: M30, M31, M39, O21, C12, C80.

\section{INTRODUCTION}

In today's fast changing economic situation, every company is trying to assess its performances regularly. In order to survive companies are taking steps to expand by accessing new markets; making product and price more attractive; satisfying cutomers; developing new strategies. Thus, managers and executives of the companies looking for a suitable tools and techniques in order to investigate the internal and external cost of the products/service, get market information, product costs, analyse customer needs and wishes, predict and assess organizational performance, as well to ensure competitive advantage in production activities.

Organizational performance (OP) is obviously a central issue in strategic management research. Several authors have analysed the organizational performance in terms of corporate strategy (Venkatraman \& Ramanujam, 1986; Murphy et.al, 1996; Carton \& Hofer, 2006; Chenhall \& Langfield-Smith, 2007).

In the literature we can find numerous findings focused on the relationship between strategic planning and performance and only few studies regarding the relations between strategic management tools and techniques and organizational performance. In other words, despite the number studies about management tools and techniques, there is just a little empirical support on this relationship. It should be noted that studies, which examine the relationship between strategic management tools and techniques and performance remain uncertain. Some of the studies have argued that utilization of management tools and techniques influences organizational performance (Iseri Say et. al, 2006; Al-Khadash \& Feridun, 2006; Indiatsy et. al, 2014). While other studies concluded that there were no clear relationship between strategic manage- 
ment tools and techniques (SMTT) and organizational performance (Rigby, 1994, Friedl \& Biloslavo, 2009; Efendioglu \& Karabulut, 2010).

Thus, in the literature there is very little empirical support to justify this relationship. For example, Rigby (1994) reflected the effect of management tools on performance by considering five performance categories (financial results, organizational integrity, performance capability, customer equity and competitive advantage). Al-Khadash and Feridun (2006) discovered a significant relationship between the level of utilization strategic tools (such as ABC, JIT, and TQM) and financial performance of 56 industrial companies in Jordan (measured by return on assets).

A study by Iseri-Say et al. (2008) is focused on the issue how the adoption of management tools (the study considered the group of 25 tools) influences organizational performance. Their findings show a significant positive relationship between competitive positioning, organizational integrity, performance capabilities, customer equity, financial results and adoption of management tools and techniques.

There are also other empirical findings which examine the effect of tools utilization on performance. For example, Friedl and Biloslavo (2009) concluded that there is no strong connection between sixteen SMTT and financial performance (net profit, return on equity, the financial independence, equity-to-debt ratio and the added value per employee among). However, they found that only two of sixteen management tools were connected with performance.

Another performance related issue is presented by Efendioglu and Karabulut (2010). They looked into the effect of most commonly used management tools on the financial performance (average sales growth per year, average profit per year, and average export growth rate per year). The effects of this relationship have been found "somewhat unanswered". Indiatsy et al (2014) investigated how the application of Porter's five forces influences organizational performance in Kenyan banking industry. They found a strong positive relationship.

It should be noted that the utilization of different techniques helps managers to improve various organizational outcomes, such as market share, revenue growth, and overall revenues. For example, AbdulHussien and Hamza (2012) noted that strategic management accounting techniques (such as activity-based costing, value chain analysis, benchmarking, balance scorecard etc.) are "reducing costs, improving product quality, and performance evaluation". Several researches concluded that higher customer satisfaction and loyalty lead to better revenue, profitability and cash-flows (Heskettet et al., 1994, Ittner \& Larcker, 1998; Williams \& Naumann, 2011). In the context of manufacturing companies Dertouzes et al. noted that high performing companies focused on customer-focused strategy tend to have high benefits from different management tools and techniques.

Management tools and techniques can be applied in different areas, such as (1) general management, (2) marketing management, (3) operations management, (4) financial management, (5) human resource management, (6) information technology, (7) management science, (8) planning and resource allocation and (9) efficiency and effectiveness (Armsrong, 1993). Tools and techniques used in general management assist managers and executives in decision-making process. Another tools used in marketing management process are responsible for identifying and satisfying customer needs. Tools and techniques involved in operations management aim to ensure 
competitive advantage in production, distribution and project management activities. The financial management area involves tools which provide the basis for decision-making for finance and predicting the performance of the company. Therefore, management tools and techniques are powerful lever which can help managers to define and develop proposed solution to the existing problems inside the organization.

Summing up, the relationship between SMTT and OP was not sufficiently examined in previous studies, therefore the purpose of this study is to extent the previous findings in the context of management tools and techniques utilization and their impact on variety organizational performance outcomes. Specifically, we analysed the manager's perceptions of strategic management tools and techniques utilization and considered the effects of SMTT on organizational performance in the context of Czech companies. The choice of management tools and performance variables for empirical research is based on the extensive literature review of existing studies with focus on strategic management tools and techniques as well as observations of studies with focus on the relation between strategic planning, strategic management tools and techniques and organizational performance. Also, we took into consideration our previous study conducted in 2012 year (Afonina \& Chalupsky, 2012).

The paper is organized as follows. The next part provides the research hypotheses, in order to examine the relationship between management tools and techniques and organizational performance. Then the research methodology is followed. The next section describes the research findings, while the last section concludes the results.

\section{RESEARCH HYPOTHESES}

The objective of this paper is to investigate the level of strategic management tools and techniques utilization and techniques as well as to examine and identify the impact of management tools utilization on organizational performance in the Czech context.

The above-mentioned studies have demonstrated evidence that utilization of SMTT are affected on organizational performance. In other words, previous studies suggested that adaption of SMTT improving financial and non-financial outcomes. For example, Iseri-Say et al. (2008) identify the effect of utilization 25 management tools on the financial performance. They include such measures as sales revenue, sales revenue growth, cash-flow, return on assets, net profit margin, profit growth, profit.

Also some researches provided evidence how particular management tool improves financial performance. Friedl and Biloslavo (2009) find a link between tools such as activity- based costing, balanced scorecard and financial performance of the Slovenian constructor sector. Efendioglu and Karabulut (2010) find a positive relation between change of sales growth, profit and utilization of "what if analysis", portfolio method (growth share matrix) and economic forecasting. Many SMTT, such as cost-benefit analysis, activity-based costing, balanced scorecard, customer profitability analysis etc., were proposed as tools that support organizational performance by improving customer satisfaction and retention, increasing market share, learning the position of company on comparison with competitors, enhancing profits. 
From the theoretical point of view and based on previous research findings, utilization of different management tools and techniques are helping companies to reflect internal and external competitive environment, structure strategic management activity, support decision-making process, customer requirements, improving financial performance outcomes, rationalizing production costs and reflect new priorities. In this sense the adoption and combination of different management tools and techniques may improve the financial and non-financial measures.

Therefore, in order to predict that there will be a relationship between strategic management tools and techniques and organizational performance the following hypotheses were formulated:

Hypothesis One

$\mathrm{H}_{1}$ : The greater number of management tools and techniques utilized by managers in Czech companies leads to better (a) sales growth, (b) return on assets, (c) return on equity and (d) cash-flow.

Hypothesis Two

$\mathrm{H}_{2}$ : The greater number of management tools and techniques utilized by managers in Czech companies leads to better (a) market share, (b) product quality, (c) new product/service offers, (d) customer satisfaction, (e) company's ability to innovate, (f) organizational adaption to change, (g) employee satisfaction.

\section{RESEARCH METHODOLOGY}

This research used the questionnaire technique that belongs to the survey strategy. A self-administered questionnaire is used in this study. It means that this type of research is completed by respondents. The on-line questionnaire method was used to collect data in order to test the hypotheses. The choice of questionnaire was influenced by the next factors:

- importance to rich a particular person

- high confidence that right person has responded

- anonymity

- easy to use for respondents

" minimum of expenses/ financial implication

- easy of data coding

The questionnaire was accompanied by a covering letter. As noted by Dillman (2000) the covering letter affects the response rate. At the beginning of questionnaire it was briefly explained the purpose of the survey, the importance of the respondent participation and respondent confidentiality. At the end of the questionnaire it was explained what the respondent need to do with a completed questionnaire.

The reliability in this study can be assessed by the next factors. At the early stage of this research, discussions with academic colleague and managers were carried out to collect information on the problem area. After which, the questions and measures of the variables in the questionnaire were drown from the intensive literature review. Regarding this, the research area was clarified in order to conduct the research. 
The methodology begins with a sampling and data collection. This is followed by performance measures used in the research. Finally, the last section describes the sample characteristics of the research.

\subsection{Sampling and Data Collection}

As was mentioned above, the list of the management tools and techniques is based on the previous studies with focus on the use of strategic tools and techniques (Hussey, 1997; Clark, 1997; Frost, 2003; Gunn \& Williams, 2007, Rigby \& Bilodeau, 2007; Aldehayyat \& Anchor, 2008). Also we took into consideration our previous study conducted in 2012 year (Afonina \& Chalupsky, 2012), where we investigated the nature of 31 management tools and techniques by determining the utilization and satisfaction level with them by companies in Czech Republic. In our previous research, it was observed that fifteen strategic management tools and techniques were used by over $50 \%$ of companies, namely: SWOT analysis, customer satisfaction analysis, price analysis, analysis of views and employee attitudes, cost-benefit analysis, analysis of customers complaints, analysis of customers' opinions and attitudes, Porter's five forces, PEST analysis, level of service analysis, market segmentation, market - share analysis, customer profitability analysis, benchmarking and analysis of customer defection (50\%) (Afonina \& Chalupsky, 2012). In this study we concentrated on 19 SMTT. The list is following (Table 1):

Tab. 1 - The list of strategic management tools and techniques.

\begin{tabular}{|l|}
\hline SWOT analysis \\
\hline Cost-benefit analysis \\
\hline Customer satisfaction analysis \\
\hline Analysis of customers complaints \\
\hline Analysis of employee satisfaction (views and employee attitudes) \\
\hline Market segmentation based on customer needs and wishes \\
\hline Price analysis \\
\hline Market share analysis \\
\hline Customer profitability analysis \\
\hline Benchmarking \\
\hline Level of service analysis \\
\hline Life cycle analysis \\
\hline Porter's 5 forces \\
\hline PEST analysis \\
\hline Portfolio methods \\
\hline Balanced scorecard \\
\hline Value chain analysis \\
\hline Activity based costring \\
\hline Critical success factors \\
\hline
\end{tabular}


Data were collected via questionnaire sent by e-mail to the companies in Czech Republic. The sample of the research consists of 91 respondents. The questionnaire includes three parts; the first part involves questions concerning the organization details (sector; industry; number of employees), demographic questions. The next part indicates the utilization level of nineteen management tools and techniques in Czech companies. Each participant was required to state which of the strategic management tools and techniques the company utilize. The participants indicated the level of utilization (Use it regularly; Use it frequently (from times to times); Use it very rarely; Do not use it). The last part raises questions concerning organizational performance from manager's (respondents) perception.

\subsection{Performance Measures}

Based on the Venkatraman and Ramanujam's (1986) there are two types of data approaches used to measure organizational performance. The subjective approach refers to primary data, while the objective approach refers to secondary data. Hult et al. (2008) examined the measurement of performance in ninety six articles in international business research. Their findings revealed that fifty five studies used primary measures and thirty nine studies used secondary measure. In other words, the subjective approach, drawing on the executive or managers perceptions of performance, has been used extensively by researches. It is important to note that primary data (managerial perception) can be more reliable than secondary data for the next reasons: (1) if it's emerging market, the objective approach can be unreliable (Lukas et. al, 2001); (2) when company do not want to give/provide financial, operational or overall performance data; (3) primary approach provides researches with information how managers understand and place on different variables of organizational performance; (4) reflect the perceptual differences (such as national, organizational, professional etc.) among the managers in different countries (Hult et al. 2008). Dess and Robinson (1984) found that subjective measures of organizational performance were correlated with objective performance measures.

Consequently, the present study focuses on subjective approach, in order to understand the manager's perception of organizational performance. Performance of the companies was measured by eleven measures of organizational performance. From an extensive literature review, we selected the following variables - cash-flow, return on equity, return on assets, sales growth, market share, customer satisfaction, product quality, new product /service offers, company ability to innovate performance, organizational adaptation to the changing conditions of the environment and employee satisfaction. These categories have been suggested as the crucial drivers of organizational performance (Rigby, 1994; Denison, 2000; Yilmaz et al., 2005). Respondents were asked to indicate on Likert five-point scale, ranging from (1) much worse to (5) much better, how their business had performed to their major competitors for each financial and non-financial performance outcome. It was used Likert five-point scale, where (1) much worse than competition and (5) much better than competition. 


\subsection{Sample Characteristics}

The features of the sample are presented in the Table 2.

Tab. 2 - Characteristics of respondents.

\begin{tabular}{|c|c|c|c|c|}
\hline Subjects & \multicolumn{4}{|l|}{ Descriptions } \\
\hline \multirow{2}{*}{ Sector } & Private & Public & & \\
\hline & $77(85 \%)$ & $14(15 \%)$ & & \\
\hline \multirow{2}{*}{ Industry } & Manufacturing & Service & Other & \\
\hline & $40(44 \%)$ & $45(49 \%)$ & $6(7 \%)$ & \\
\hline \multirow[t]{2}{*}{ Size of company } & 0-49 employees & $\begin{array}{c}50-250 \text { employ- } \\
\text { ees }\end{array}$ & + 250 employees & \\
\hline & $14(15.4 \%)$ & $28(30.8 \%)$ & $49(53.8 \%)$ & \\
\hline \multirow[t]{2}{*}{ Position } & $\begin{array}{c}\text { General Man- } \\
\text { ager }\end{array}$ & $\begin{array}{c}\text { Finance Direc- } \\
\text { tor }\end{array}$ & $\begin{array}{l}\text { Marketing } \\
\text { Manager }\end{array}$ & CEO(owner) \\
\hline & $16(17.6 \%)$ & $22(24.2 \%)$ & $40(44 \%)$ & $13(14.3 \%)$ \\
\hline \multirow{2}{*}{$\begin{array}{l}\text { Experience in } \\
\text { position }\end{array}$} & $>2$ years & $2-5$ years & $6-10$ years & $<10$ years \\
\hline & $7(7.7 \%)$ & $22(24.2 \%)$ & $37(40.7 \%)$ & $25(27.5 \%)$ \\
\hline
\end{tabular}

The characteristics of the respondents were classified by position and experience in current position. The survey of this study conducted on 40 marketing managers, 22 finance directors, 16 general managers and 13 chief executive officers of 91 companies that operate in Czech Republic. The working time in the position of the respondents vary between $6-10$ years $(40.7 \%)$, more than 10 years $(27.5 \%) ; 2-6$ years $(24.2 \%)$ and less than 2 years $(7.7 \%)$. The characteristics of the companies were classified by sector/ nature of business, and size of company. Most of the companies participated in our study is working on the private sector 77 (85\%), while the companies working in public sector of the economy represent $15 \%$ of all selected companies. Forty of the participating companies operate in manufacturing sector, while forty-five companies are in service sector.

According to the size of the company, the research includes 49 large companies (the companies with more than 250 employees) and 42 small and medium-sized enterprises. The objective of our survey was to better understand manager's perception of strategic management tools and techniques, as well as to explore and identify the impact of strategic management tools and techniques on organizational performance. The e-mail survey included the invitation letter explaining the purpose of the research. Particular attention has been paid to anonymity of respondents. Respondents were not required to identify themsleves or their company.

The obtained data were analyzed through SPSS (statistical package for the social sciences) software. 


\section{DISCUSSION AND RESEARCH FINDINGS}

The respondents were asked to indicate which tools and techniques are currently being used in their companies on a four-point scale (where $1=$ use it regularly, $2=$ use is frequently (from times to times), $3=$ use it very rarely, $4=$ do not use it). As no definitive list of strategic management tools and techniques was available, a list of SMTT is based on previous empirical studies in this stream. Figure 1 shows the frequency of utilization of different strategic management tools and techniques by respondents. Our results showed that companies are using SWOT analysis, customer satisfaction analysis, price analysis, cost-benefit analysis, market share analysis, analysis of employee satisfaction analysis of customers complaints, Porter's 5 forces, service analysis, PEST analysis, customer profitability analysis, benchmarking and methods of portfolio analysis (over $50 \%$ of companies utilize these tools). The results show less utilization of tools such as balanced scorecard, life-cycle analysis, value chain analysis, activity based costing and critical success factors by Czech companies.

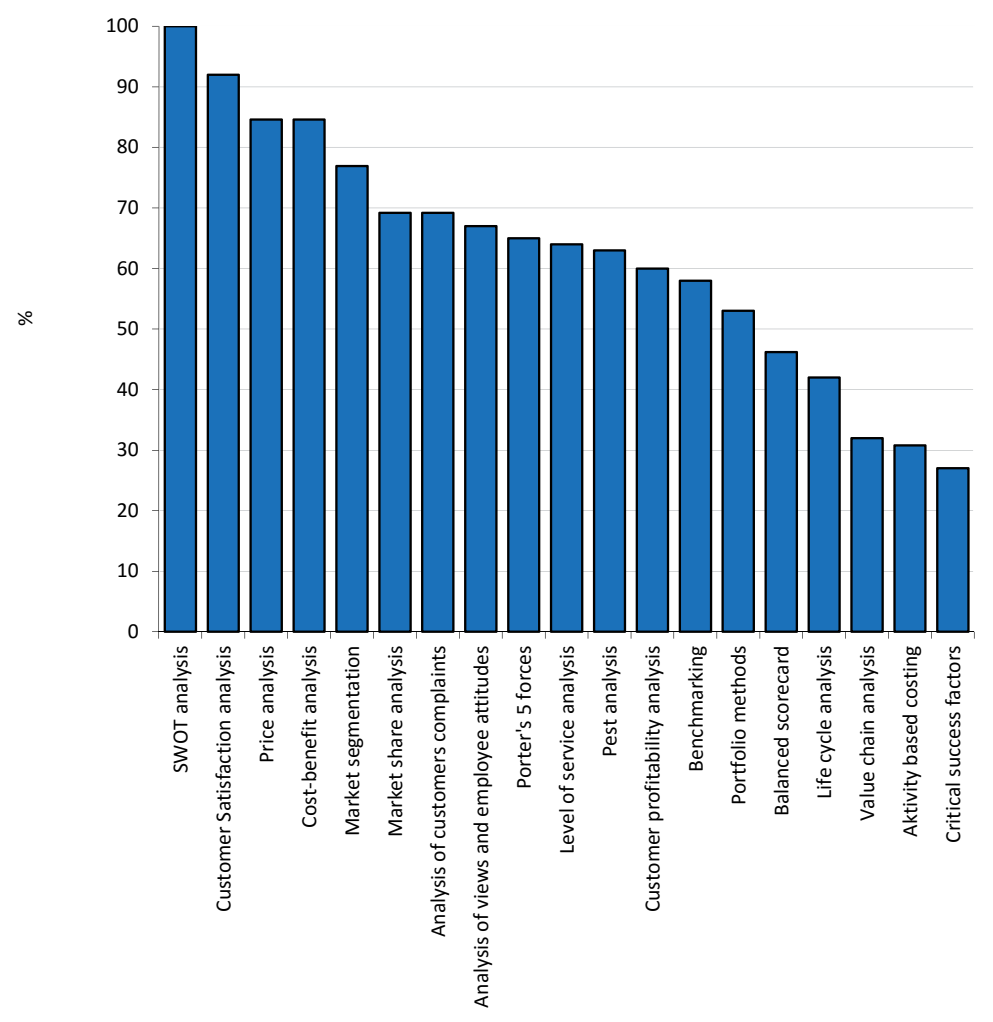

Fig. 1 - Use of strategic management tools and techniques. Source: Own research

These results support our previous research findings obtained in 2012. We achieved almost a similar distribution of management tools utilization by sampled companies in Czech Republic. SWOT analysis appears again to be a favourite tool among Czech organizations. The high level 
of utilization of such tools as SWOT analysis, customer satisfaction analysis, market segmentation, analysis of customers complaints, Porter's 5 forces, pest analysis customer profitability analysis benchmarking and portfolio methods, demonstrates few important priorities of sampled organizations, namely, customer satisfaction and interest in external and internal factors of companies' environment.

The Mann-Whitney U test was undertaken to determine whether any significant difference existed between the industry type (manufacture/service) regarding utilization of strategic management tools and techniques (see Table 3). The results indicate statistically significant difference between two sectors in utilization of SWOT analysis $(p=0.010)$, portfolio methods $(p=0.040)$, level of service analysis $(p=0.001)$ and customer profitability analysis $(p=0.003)$. It was identified that portfolio methods, level of service analysis and customer profitability analysis are used more by the manufacture sector, while SWOT analysis is utilized more by organizations working in service sector. As for other SMTT, no significant difference was found regarding the utilization of SMTT between two sectors.

Tab. 3 - Mann-Whitney U test.

\begin{tabular}{|l|c|c|c|c|}
\hline Testing criteria & $\begin{array}{c}\text { Mann-Whitney } \\
\text { U }\end{array}$ & Wilcoxon W & Z & $\begin{array}{c}\text { Asymp. Sig. } \\
\text { (2-tailed) }\end{array}$ \\
\hline SWOT analysis & 629,000 & 1664,000 & $-2,591$ & 0,010 \\
\hline Balanced scorecard & 816,000 & 1636,000 & $-0,807$ & 0,420 \\
\hline Benchmarking & 798,500 & 1618,500 & $-0,951$ & 0,341 \\
\hline PEST analysis & 777,000 & 1597,000 & $-1,137$ & 0,256 \\
\hline $\begin{array}{l}\text { Analysis of views and em- } \\
\text { ployee attitudes }\end{array}$ & 824,500 & 1644,500 & $-0,725$ & 0,469 \\
\hline Portfolio methods & 677,000 & 1497,000 & $-2,049$ & 0,040 \\
\hline Value chain analysis & 805,500 & 1625,500 & $-0,920$ & 0,358 \\
\hline Cost-benefit analysis & 828,500 & 1863,500 & $-0,866$ & 0,386 \\
\hline Customer satisfaction analysis & 785,000 & 1820,000 & $-1,077$ & 0,282 \\
\hline Porter's 5 forces & 761,000 & 1581,000 & $-1,299$ & 0,194 \\
\hline Critical success factors & 852,000 & 1672,000 & $-0,521$ & 0,602 \\
\hline Life cycle analysis & 782,000 & 1602,000 & $-1,109$ & 0,267 \\
\hline Market segmentation & 738,500 & 1558,500 & $-1,506$ & 0,132 \\
\hline Activity based costing & 712,000 & 1532,000 & $-1,820$ & 0,069 \\
\hline Price analysis & 721,000 & 1541,000 & $-1,942$ & 0,052 \\
\hline $\begin{array}{l}\text { Analysis of customers com- } \\
\text { plaints }\end{array}$ & 769,000 & 1589,000 & $-1,364$ & 0,173 \\
\hline Market share analysis & 814,500 & 1634,500 & $-0,834$ & 0,404 \\
\hline Level of service analysis & 545,500 & 1365,500 & $-3,346$ & 0,001 \\
\hline Customer profitability analysis & 594,000 & 1414,000 & $-2,929$ & 0,003 \\
\hline
\end{tabular}




\subsection{Test of Hypotheses}

According to the literature review, there are not so many empirical studies that investigate the relationship between strategic management tools and techniques and organizational performance. One the one hand, some of research supports assertion that utilization of different management tools and techniques have better performance outcomes. On the other hand, some of empirical studies have concluded that relationship between strategic management tools and techniques and organizational performance remains unanswered.

In order to test the relationship between strategic management tools and techniques and organizational performance, there is a necessity to select suitable measures of organizational performance. The literature presents different measures of organizational performance. According to Carton and Hofer (2006) there is "no study that has successfully proposed and empirically tested a multidimensional model to characterise performance of the companies".

For example, Al-Khadash and Feridun (2006) measured organizational performance by return on assets. Rigby (1994) and Iseri-say et. al (2008) measured performance by 25 outcomes, namely, sales revenue, sales revenue growth, profit, profit growth, net profit margin, return on asset, cash flows, innovative work-processes, organizational and cultural adaptation to change, employee satisfaction and loyalty, quality of workforce, and level of institutionalization, new product/service development, product/service quality, after-sales service quality, production flexibility and costs, delivery speed, customer satisfaction and loyalty, customer knowledge and interactions, responsiveness to customer needs, market research, market share, new product/service offers and speed to market, competitive and flexible pricing, and effective and low cost supply/distribution.

Some studies focused only on the financial outcomes of organizational performance. For example, Friedl and Biloslavo (2009) measured performance by equity, return on equity, the financial independence indicator, which reflects the ratio between the equity and the assets of a company, the horizontal financial structure indicator, and the added value per employee. Efendioglu and Karabulut (2010) also investigated the financial performance outcomes, namely sales growth, profit, and export growth.

Since there is no successfully proposed and empirically tested a multidimensional model of organizational performance, measures of $\mathrm{OP}$ were based on items derived from a number of previous academic literature (Rigby, 1994; Denison, 2000; Yilmaz et al., 2005). A list of 11 financial and non-financial outcomes of organizational performance was used.

Before conducting the multiple regression analysis, it was important to determine whether a linear relationship between strategic management tools and techniques and organizational performance appears. In case it appears a linear relationship between variables exists. It means that it is possible to proceed a multiple regression analysis. In case there is no linear relationship, a different type of analysis maybe preferred. One way to test whether two variables are linearly related is by determining the correlation between them. Correlation analysis is a widely used method in scientific research papers. Generally it describes the effect that two or more variables occur together. 
A correlation indicates the strength and direction of linkage between variables by correlation coefficient $(r)$. Its value varies between +1 and -1 . A positive $r$ value indicates a positive relationship between variables. In other words if one variable increases, the other variable also increases. A negative $r$ value indicates a negative relationship between variables. It means, if one variable increases, the other variable decreases. The correlation coefficient can be calculated by the next formula:

$$
r=\frac{\mathrm{n}(\Sigma \mathrm{xy})-(\Sigma \mathrm{x})(\Sigma \mathrm{y})}{\sqrt{\left[\mathrm{n} \Sigma \mathrm{x}^{2}-(\Sigma \mathrm{x})^{2}\right]\left[\mathrm{n} \Sigma \mathrm{y}^{2}-(\Sigma \mathrm{y})^{2}\right]}}
$$

where, $\mathrm{n}$ - number of pairs of data; $\mathrm{x}$ - values in first set of data; $\mathrm{y}$ - values in second set of data

Tab. 4. - Correlation between the number of SMTT utilized and organizational performance outcomes.

\begin{tabular}{|c|c|c|}
\hline \multicolumn{2}{|l|}{ Organizational performance } & $\begin{array}{c}\text { Number of } \\
\text { SMTT }\end{array}$ \\
\hline \multicolumn{3}{|l|}{ Financial performance } \\
\hline \multirow{3}{*}{ Sales growth } & Correlation Coefficient & 0,610 \\
\hline & Sig. (2-tailed) & 0,000 \\
\hline & $\mathrm{N}$ & 91 \\
\hline \multirow{3}{*}{ ROA } & Correlation Coefficient & 0,446 \\
\hline & Sig. (2-tailed) & 0,000 \\
\hline & $\mathrm{N}$ & 91 \\
\hline \multirow{3}{*}{$\mathrm{ROE}$} & Correlation Coefficient & 0,421 \\
\hline & Sig. (2-tailed) & 0,000 \\
\hline & $\mathrm{N}$ & 91 \\
\hline \multirow{3}{*}{ Cash-flow } & Correlation Coefficient & 0,373 \\
\hline & Sig. (2-tailed) & 0,000 \\
\hline & $\mathrm{N}$ & 91 \\
\hline \multicolumn{3}{|l|}{ Non-financial performance } \\
\hline \multirow{3}{*}{ Market share } & Correlation Coefficient & 0,531 \\
\hline & Sig. (2-tailed) & 0,000 \\
\hline & $\mathrm{N}$ & 91 \\
\hline \multirow{3}{*}{ Product quality } & Correlation Coefficient & 0,419 \\
\hline & Sig. (2-tailed) & 0,000 \\
\hline & $\mathrm{N}$ & 91 \\
\hline \multirow{3}{*}{ New product/service offers } & Correlation Coefficient & 0,480 \\
\hline & Sig. (2-tailed) & 0,000 \\
\hline & $\mathrm{N}$ & 91 \\
\hline
\end{tabular}




\begin{tabular}{|l|l|l|}
\hline \multirow{4}{*}{ Customer satisfaction } & Correlation Coefficient & 0,648 \\
\cline { 2 - 3 } & Sig. (2-tailed) & 0,000 \\
\cline { 2 - 3 } Company ability to innovate & $\mathrm{N}$ & 91 \\
\hline \multirow{4}{*}{ Organization adaption to change } & Correlation Coefficient & 0,472 \\
\cline { 2 - 3 } & Sig. (2-tailed) & 0,000 \\
\cline { 2 - 3 } & $\mathrm{N}$ & 91 \\
\hline \multirow{4}{*}{ Employee satisfaction } & Sig. (2-tailed) & 0,524 \\
\cline { 2 - 3 } & $\mathrm{N}$ & 0,000 \\
\hline \multirow{2}{*}{ Correlation is significant at the 0.01} & 91 \\
\hline & Correlation Coefficient & 0,405 \\
\cline { 2 - 3 } & Sig. (2-tailed) & 0,000 \\
\cline { 2 - 3 } & $\mathrm{N}$ & 91 \\
\hline
\end{tabular}

The correlation analysis, Table 4, revealed that the relationship between number of strategic management tools and techniques utilized by managers and organization performance outcomes is statistically significant $(p<.001)$ for a two-tailed test, based on a sample of 91 companies. The findings indicate that there is no negative relationship between variables.

For further analysis, the multiple regression analysis was used. Multiple linear regression helps us to model the relationship between two or more explanatory variables and a response variable by fitting a linear equation to observed data. The following performance measures, namely, cash-flow, ROE, ROA, sales growth, market share, customer satisfaction, product quality, new product/service offers, company ability to innovate, organizational adaption to change and employee satisfaction - were regressed on the independent variable measured by number of SMTT utilized by companies.

The results of testing hypothesis H1 shows a significant relationship between financial measures (namely sales growth, return on assets, return on equity and cash-flow) and utilization of strategic management tools and techniques. Based on the table 5, it might be argued that sales growth yielding the highest $r$-square. R-square is the proportion of variance in the dependent variable (measured by sales growth, ROA, ROE and cash-flow) which can be explained by the independent variables (measured by number of SMTT). The results suggest that utilization of management tools and techniques $\left(\mathrm{R}^{2}=0.372\right)$ is more associated with sales growth (in category of financial performance outcomes). R-square was found to be 0.372 indicating that management tools and techniques utilization explain approximately 37 per cent of the variance in sales growth outcomes. Looking at the p-value of the t-test for each variable, we can see that utilization of strategic management tools contributes to all financial performance outcomes. 
Tab. 5 - The results of the regression model for the financial performance outcomes of strategic management tools and techniques utilization. Source: Own calculations.

\begin{tabular}{|l|l|l|l|l|l|l|l|}
\hline $\begin{array}{l}\text { Dependent } \\
\text { variables }\end{array}$ & R & F & Sig & $\begin{array}{l}\text { Bun- } \\
\text { std. }\end{array}$ & $\begin{array}{l}\text { t-val- } \\
\text { ues }\end{array}$ & p & Bstd. \\
\hline Sales growth & 0.372 & 52.613 & 0.000 & 0.577 & 7.253 & 0.000 & 0.610 \\
\hline ROA & 0.199 & 22.096 & 0.000 & 0.357 & 4.701 & 0.000 & 0.446 \\
\hline ROE & 0.177 & 19.190 & 0.000 & 0.451 & 4.381 & 0.000 & 0.421 \\
\hline Cash-flow & 0.139 & 14.401 & 0.000 & 0.452 & 3,795 & 0.000 & 0.373 \\
\hline
\end{tabular}

In order to test the effect of management tools and techniques on non-financial outcomes, we used the next performance measures - market share, product quality, new product/service offers, customer satisfaction, company ability to innovate, organizational adaption to change, employee satisfaction.

The findings show a significant relationship between non-financial outcomes and strategic management tools and techniques utilization. It may be noted that the relationship between SMTT utilization and customer satisfaction is much stronger (Bstd. $=0.648 ; \mathrm{p}<0.001$ ) than in product quality (Bstd. $=0.419 ; \mathrm{p}<.001)$; new product/service offers (Bstd. $=0.480 ; \mathrm{p}<0.001)$; company ability to innovate $(\mathrm{Bstd} .=0.472 ; \mathrm{p}<0.001)$; organizational adaption to change $(\mathrm{Bstd} .=0.524 ; \mathrm{p}$ $<0.001$ ); and employee satisfaction (Bstd. $=0.405 ; \mathrm{p}<0.001)$. These results tend to confirm that there is a positive relationship between strategic management tools and techniques utilization and non-financial outcomes (see Table 6).

Tab. 6 - The results of the regression model for the non-financial performance outcomes of strategic management tools and techniques utilization. Source: Own calculations.

\begin{tabular}{|l|l|l|l|l|l|l|l|}
\hline Dependent variables & \multicolumn{1}{|c|}{$\mathrm{R}^{2}$} & Fchange & Fsig & Bunstd. & t-values & $\mathrm{p}$ & Bstd. \\
\hline Market share & 0.282 & 35.016 & 0.000 & 0.266 & 5.917 & 0.000 & 0.531 \\
\hline Product quality & 0.176 & 18.974 & 0.000 & 0.590 & 4.356 & 0.000 & 0.419 \\
\hline $\begin{array}{l}\text { New product/service } \\
\text { offers }\end{array}$ & 0.230 & 26.635 & 0.000 & 0.708 & 5.161 & 0.000 & 0.480 \\
\hline Customer satisfaction & 0.420 & 64.572 & 0.000 & 0.772 & 8.036 & 0.000 & 0.648 \\
\hline $\begin{array}{l}\text { Company ability to in- } \\
\text { novate }\end{array}$ & 0.223 & 25.517 & 0.000 & 0.500 & 5.051 & 0.000 & 0.472 \\
\hline $\begin{array}{l}\text { Organizational adaption } \\
\text { to change }\end{array}$ & 0.275 & 33.759 & 0.000 & 0.608 & 5.810 & 0.000 & 0.524 \\
\hline Employee satisfaction & 0.164 & 17.508 & 0.000 & 0.556 & 4.184 & 0.000 & 0.405 \\
\hline
\end{tabular}

A positive significant relationship was found between organizational performance measures (namely cash-flow, return on equity, return on assets, sales growth, market share, customer satisfaction, product quality, new product /service offers, company ability to innovate performance, 
organizational adaptation to the changing conditions of the environment, employee satisfaction) and the use of management tools and techniques. These results indicate that utilization of strategic management tools and techniques helps companies to understand their customer by analysing customer complaints, their needs and wishes, opinions and attitudes; to adapt products and expand to new markets. Also management tools and techniques allow companies to increase financial outcomes (such as cash-flow, return on assets, return on equity and sales growth).

Summing up, in this study, we have found that financial and non-financial performance outcomes are affected by strategic management tools and techniques utilization. Such result is not fully confirmed by the previous studies examining this relationship. These mixed findings may be explained by arguing that studies used different list of strategic management tools and techniques, analyzed different industries. Also different results may be explained by considering the different determinants of financial and non-financial performance measures. It should be noted, that some of the studies investigated the impact of management tools on organizational performance based on financial performance outcomes only. In other words, these studies did not consider the non-financial outcomes of the companies.

\section{CONCLUSION}

This study provides empirical evidence regarding strategic management tools and techniques utilization as well as exploring relationship between strategic management tools and techniques utilization and organizational performance in Czech companies.

The findings indicate that the most commonly used strategic management tools and techniques are SWOT analysis, customer satisfaction analysis, price analysis, cost-benefit analysis, market share analysis, analysis of employee satisfaction, analysis of customers complaints, Porter's 5 forces, service analysis, PEST analysis, customer profitability analysis, benchmarking and methods of portfolio analysis (over 50 per cent of companies utilize these tools and techniques). The popularity of SWOT analysis is not surprising because this technique is considered to be very popular tool not only in Czech Republic but also among UK organizations (Gun and Williams, 2007), Australian organizations (Frost, 2003, Finland organizations (Stenfors et.al, 2007), Egypt organizations (Elbanna 2007) and Jordan organizations (Aldehayyat et.al, 2011). However the high level of utilization of SWOT analysis may be contrasted with the lower utilization of Porter's 5 forces, PEST analysis, benchmarking, portfolio methods life-cycle analysis and critical success factors. All these tools focused on analyzing internal and external factors that can affect the performance of the companies. The utilization of customer satisfaction analysis, market segmentation, customer complaints analysis, customer profitability analysis, reflects the interest in customers. These tools allow companies to better understand and satisfy the needs of company's customers.

The research findings indicate extensive use of strategic management tools and techniques among Czech companies. It has been found that 14 of 19 SMTT used by over $50 \%$ of sampled organizations. The Mann-Whitney $U$ test was undertaken to determine whether any significant difference between type of industry and strategic management tools and techniques utilization exists. The results indicate no statistically significant difference between type of industry 
and SMTT, except SWOT analysis, portfolio methods, level of service analysis and customer profitability analysis. The same little variation between strategic management tools and techniques utilization and manufacturing or service organizations were found in previos studies (Glaister \& Falsaw, 1999; Elbanna, 2007; Aldehayyat \& Anchor, 2008). The correlation analysis was conducted to assess the relathionship between strategic management tools and techniques and organizational performance. It was found a positive significant relathionship between these variables.

Furthermore, the paper provides new evidence to understand the effect of strategic management tools and techniques utilization on organizational performance, drawing on data from Czech companies. To have a more balanced impression of organizational performance we used the combination of financial and non-financial outcomes. The need of non-financial measures has been mentioned in many studies. Academics have mentioned many benefits of using nonfinancial measures, such us reflecting and affecting financial value of the companies, helping to link actions with financial results and focusing on long-term organizational strategies. By using multiple regression analysis we examined the relationship between management tools and techniques and organizational performance. It was found that there is a strong a positive relationship between strategic management tools and techniques utilization and financial and non-financial performance outcomes.

Several limitations should be mentioned with regard to our study. One of the limitations is the fact that we observed only Czech companies. Another limitation is that study did not examine moderating effects that may influence the management tools and techniques-performance relationship (such as company size, environment turbulence, etc.). Another potential limitation concerns the determination of organizational performance. Studies which measure organization performance obviously are facing difficulties with determination of performance measures.

The scope of future research may be extended by examining other different management tools and techniques and organizational performance outcomes, which may reflect additional interesting relations in a longer time series.

Despite these limitations, the study provides the evidence how strategic management tools and techniques can affect performance. We considered a broad range of strategic management tools and techniques. This is advantage over prior studies that considered only two or three management tools and relied only on financial performance outcomes. In conclusion, we believe that our study will prompt researchers to conduct additional research in this area.

\section{References}

1. Abdulhussien, M., H., \& Hamza, S. (2012). Strategic Management Accounting Techniques in Romanian Companies: An Empirical Study. Studies in Business and Economics, 126 - 140.

2. Afonina, A., \& Chalupský, V. (2012). The Current Strategic Management Tools and Techniques: The evidence from Czech Republic. Journal of Economics and Management, 17 (4), 1535-1544. http://dx.doi.org/10.11118/actaun201361040833 
3. Al-khadash, H. A., \& Feridun, M. (2006). Impact of Strategic Initiatives in Management Accounting on Corporate Financial Performance: Evidence from Amman Stock Exchange. Journal of Managing Global Transitions, 4 (4), 299 - 312, from http://ssrn.com/abstract=938782

4. Aldehayyat, J., \& Anchor, J. (2008). Strategic planning tools and techniques in Jordan: awareness and use. Strategic Change Journal, 17 (7-8), 282-293. DOI: 10.1002/jsc.833

5. Aldehayyat, J., Khattab, A., \& Anchor, J. (2011). The use of strategic planning tools and techniques by hotel in Jordan. Management Research Review, 34 (4), 477 - 490.

6. Armstrong, M. (1993). A Handbook of Management Techniques. USA: Nichols Publish.

7. Carton, R., \& Hofer, C. (2006). Measuring Organizational Performance: Metrics for Entrepreneurship and Strategic Management Research. Great Britain: Edward Elgar Publishing.

8. Chenhall, R. H., \& Langfield-Smith., K. (1998). The Relationship between Strategic Priorities, Management Techniques and Management Accounting: An Empirical Investigation Using a Systems Approach. Journal of Accounting, Organizations and Society, 23 (3), 243-264. DOI: 10.1016/S0361-3682(97)00024-X

9. Clark, D. (1997). Strategic management tool usage: a comparative study. Strategic Change Journal, 6 (7), 417-427. DOI: 10.1002/(SICI)1099-1697(199711) 6:7<417::AIDJSC281>3.0.CO;2-9

10. Dillman, D. A. (2000). Mail and Internet Surveys: The Tailored Design Method (Vol. 2.). New York: Wiley.

11. Denison, D. R. (2000). Organizational culture: can it be a key lever for driving organizational change. The handbook of organizational culture. London: Wiley.

12. Dertouzos, M. L., Lester, R. K., \& Solow, R. M. (1989). Made in America Regaining the Productive Edge. New York: HarperPerennial ed edition.

13. Dess, G. G., \& Robinson, R. B. (1984). Measuring organizational performance in the absence of objective measures: the case of the privately-held firm and conglomerate business unit. Strategic Management Journal, 5, 265-73. DOI: 10.1002/smj.4250050306

14. Elbanna, S. (2007). The nature and practice of strategic planning in Egypt. Strategic Change, 16, 227-243. doi:10.1002/jsc.797

15. Frost, F. (2003). The use of strategic tools by small and medium-sized enterprises: an Australasian study. Strategic Change, 12(1), 49-62. doi:10.1002/jsc.607

16. Glaister, K., \& Falsow, R. (1999). Strategic planning: still going strong? Long Range Plannin, 32 (1), 107-16.

17. Gunn, R., \& Williams, W. (2007). Strategic tools: an empirical investigation into strategy in practice in the UK. Strategic Change Journal, 16, 201-216. DOI: 10.1002/jsc.799

18. Efendioglu, A., \& Karabalut, A. (2010). Impact of Strategic Planning on Financial Performance of Companies in Turkey. International Journal of Business and Management, 5 (4), 3-12. DOI:10:5539/ijbm.v5n4p3 
19. Friedl, P., \& Biloslavo, R. (2009). Association of Management Tools with the Financial Performance of Companies: The Example of the Slovenian Construction Sector. Journal of Managing Global Transition, 7 (4), 383-402, from http://www.fm-kp.si/zalozba/ISSN/15816311/7_383-402.pdf

20. Frost, F. (2003). The use of strategic tools by small and medium-sized enterprises: an Australasian study. Journal of Strategic Change, 12 (1), 49-62. DOI: 10.1002/jsc.607

21. Gunn, R., \& Williams, W. (2007). Strategic tools: an empirical investigation into strategy in practice in the UK. Strategic Change Journal, 16 (5), 201-216. DOI: 10.1002/jsc.799

22. Heskett, J. L., Sasser, W. E., \& Schlesinger, L., A. (1994). The Service Profit Chain: How Leading Companies Link Profit and Growth to Loyalty, Satisfaction, and Value. New York: Free Press.

23. Hult, G., Ketchen JR, J., Chabowski, R., Hamman, K., Dykes, J., Pollitte A., \& Cavusgil, T. (2008). An assessment of the measurement of performance in international business research. Journal of International Business Studies, 39, 1064-1080. doi:10.1057/palgrave. jibs. 8400398

24. Hussey, D. (1997). Glossary of techniques for strategic analysis. Strategic Change Journal, 6 (2), 97-115. DOI: 10.1002/(SICI)1099-1697(199703)6:2<97::AID-JSC223>3.0.CO;2-I

25. Indiatsu, C. M., Mwangi, M. S., \& Mandere E., N. (2014). The Application of Porter's Five Forces Model on Organization Performance: A Case of Cooperative Bank of Kenya Ltd. European Journal of Business and Management, 6 (16), 75-85, from http://www.iiste.org/ Journals/index.php/EJBM/article/view/13364

26. Ittner, C. D., \& Larcker, D., F. (1998). Are non-financial measures leading indicators of financial performance? An analysis of customer satisfaction. Journal of Accounting Research, 36, 1-46. DOI: $10.2307 / 2491304$

27. Iseri-Say, A., Toker, A., \& Kantur, D. (2008). Do popular management techniques improve performance? Journal of Management Development, 27 (7), 660-677. DOI: http://dx.doi. org/10.1108/02621710810883580

28. Lukas, B., Tan, T., \& Hult, G. (2001). Strategic fit in transitional economies: the case of China 's electronics industry. Journal of Management, 27 (4), 409-429. DOI: http://dx.doi. org/10.2139/ssrn.1552270

29. Murphy, G., Trailer, J., \& Hill, R. (1996). Measuring performance in entrepreneurship research. Journal of Business Research, 36, 15-23. DOI: 10.1016/0148-2963(95)00159-X

30. Robert Francis Group. Retrieved from http://www.rfgonline.com/

31. Rigby, D. (1994). Managing the Management Tools. Journal of Planning Review, 22 (5), 20-24. doi:10.1108/eb054477

32. Rigby, D., \& Bilodeau, B. (2007). Bain's global 2007 management tools and trends survey. Journal of Strategy \& Leadership, 35 (5), 9-16. DOI: http://dx.doi.org/10.1108/108785707108 19161

33. Stenfors, S., Tanner, L., \& Haapalinna, I. (2004). Executive Use of Strategy Tools: Building Shared Understanding through Boundary Objects. Frontiers of E -Business research, 635-645. 
34. Venkatraman, N., \& Ramanujam, V. (1986), Measurement of business performance in strategy research: a comparison of approaches. Academy of Management Review, 11 (4), 801-814. DOI: $10.5465 / A M R .1986 .4283976$

35. Williams, P., \& Naumann, E. (2011). Customer satisfaction and business performance: a firm level analysis. Journal of Services Marketing, 25 (1), 20-32. DOI: http://dx.doi.org/10.1108 $/ 08876041111107032$

36. Yilmaz, C., Alpkan, L., \& Ergun, E. (2005). Cultural determinants of customer- and learning-oriented value systems and their joint effects on firm performance. Journal of Business Research, 58, 1340-1352. DOI: 10.1016/j.jbusres.2004.06.002

\section{Contact information}

Ing. Anna Afonina

Brno University of Technology, Faculty of Business and Management

Kolejni 4, 61200 Brno, Czech Republic

Email:afonina@fbm.vutbr.cz. 